\title{
Narcoterrorism as a Threat \\ to the National Security \\ of the Russian Society
}

\author{
Dmitry D. Nevirko* \\ Siberian Federal University \\ 79 Svobodny, Krasnoyarsk, 660041, Russia
}

Received 13.10.2016, received in revised form 27.11.2016, accepted 10.01.2017

The article presents the analysis of concepts of narcoterrorism and the author's understanding of this phenomenon. It describes the state of the drug situation in the world and in the Russian Federation. The author examines factors that undermine the national security system and justifies the need of cooperation between the law enforcement bodies of Russia and the competent authorities of foreign states to counter illicit drug trafficking. The article also formulates the priorities for combating the threat of drugs and narcoterrorism in the Russian society.

Keywords: narcoterrorism, drug situation, terrorism, narcotization of population, combating (countering) narcoterrorism, national security.

DOI: 10.17516/1997-1370-0020.

Research area: sociology.

A concept of narcoterrorism was first formulated in 1983 by the Peruvian president Belaunde Terry to denote terrorist-like attacks against the drug enforcement police. Impeding the administration of justice, drug criminals used terrorist methods to influence the country's policy. The phenomenon received public attention in 1985, when the Medellin cartel joined forces with a terrorist group and attacked the Supreme Court in Bogota (Colombia) to prevent the extradition of several top cocaine lords to the United States. Eleven high judges were killed ${ }^{1}$.

Later the narcoterrorism concept was formulated in two key notions. One of them focuses on the drug gangs who use terrorist methods to protect their own drug activities, for example killing judges or journalists ${ }^{2}$; and the other focuses on the involvement of terrorist organizations in drug trafficking to finance their activities.

In order to cover both aspects, D. Davids introduced a bilateral definition: "On the one hand, $[\ldots .$.$] terrorism that aims to protect and$ support the activities of illegal drug traffickers; and on the other hand, terrorism of organizations that use the financial profits of narcotrafficking to support their political, religious or other goals"3.

In 1992, the American Gregory Petrakis gave the integral definition showing narcoterrorism as the three directions:

(C) Siberian Federal University. All rights reserved

* Corresponding author E-mail address: ndd-krasnoyarsk@mail.ru 
1) the use of the drug trade by radical and terrorist organizations to support their political beliefs;

2) support for the "drugs-for-guns" operation and other drug operations by the government to enhance their financial and political opportunities;

3) the use of terrorist tactics (bombings, kidnappings, murders) by organized criminal groups involved in drug trafficking to increase income (maximize their profits).

Jonas Hartelius, a well-known expert in research in the area of drug control and drug prevention, states: "The simplest way of describing narcoterrorism is, perhaps, as a part of an illegal complex of drugs, violence and power, where the illegal drug trade and the illegal exercise of power have become aggregated in such a way that they threaten democracy and the rule of law. According to Makarenko, the complex can be described as a continuum, where one endpoint is occupied by specialized drug crimes with commercial motives and the other endpoint - by specialized terrorist activities with ideological motives"4.

In our opinion, narcoterrorism is the activity in merging drug business with organized crime based on the ideology of economic gain, political, social, ethnic and confessional contradictions, as well as countering the political system. This activity is carried out for the purpose of public security violation, terrorizing the population or influencing the decision-making authorities to be favourable to terrorists or to satisfy their unlawful property and other interests.

Thus, the concept of "narcoterrorism" refers not only to the vigorous activity of terrorist organizations financed by the drug business, but also directly to the activities of the organized criminal groups involved in drug trafficking and attempting to impose the terrorist ideology on the state power by carrying out terrorist acts.
Of course, in practice, the definition of narcoterrorism is rather a politically constructed concept than a legal definition. However, it poses a direct threat to the national security of any state, since the number of victims from narcoterrorism is hundreds times more than those from terrorist acts. Not by chance, on December 9, 1994, The UN General Assembly adopted the Declaration on Measures to Eliminate International Terrorism, which focuses on a concern "about the growing and dangerous links between terrorist groups and drug traffickers and their paramilitary gangs, which resort to all types of violence, thus endangering the constitutional order of states and violating basic human rights"

Currently, terrorism intersects with different types of organized crime: arms and human trafficking, corruption, money laundering, etc. Connection between the drug trafficking, terrorist, radical organizations and groups is the most significant. The income derived from the criminal drug trafficking is used to finance terrorist activities.

Cooperation between drug traffickers and terrorist organizations or armed movements has not been predetermined. There were a lot of circumstances against it: the fundamental differences in ideology, social status ambitions and attitude to the state structures. In the 1980's, murder, kidnapping and other violent crimes occurred among the drug dealers and terrorist organizations in South America. However, after some time, peace was achieved and some kind of co-operation developed, which, in the late 1980's, became such an important part of the game around drugs that the US government authorities started talking about narcoterrorism as a driving force for both sides ${ }^{6}$.

The state of narcoterrorism can be estimated through the analysis of its basic characteristics, such as a drug situation, a drug threat and a drugrelated crime. 
Every year the global drug situation is summarized by the United Nations Office on Drugs and Crime (UNODC) in its annual World Drug Report ${ }^{7}$, according to which 1 in 20 adults or a quarter of a billion people between the ages of 15 and 64 years took at least one drug in 2014. It is roughly the equivalent of the combined populations of France, Germany, Italy and the United Kingdom. The impact of the drug usage in terms of its consequences on health continues to be devastating: 1.6 million people are living with HIV, 6 million - with hepatitis C. With estimated 207400 drug-related deaths in 2014, corresponding to 43.5 deaths per million people aged 15-64, the number of drug-related deaths worldwide has also remained stable, although unacceptable and preventable. Only one out of 6 drug users has access to treatment.

The most common type of addiction is cannabis - more than 160 million people are being involved in it.

26 million people abuse amphetamine drugs. The global production of amphetamine and methamphetamine is 300 tons.

The number of opiate abusers is 16 million, 10 million of which abuse heroin. In 2014 the global opium production was 7554 tons, and 657 tons of heroin can be produced of this amount. The cocaine production is estimated at 900 tons.

Currently these negative trends are much higher both in quantitative and qualitative indicators ${ }^{8}$.

It is no secret that the drug business is an extremely profitable activity. In fact, it is a multibillion-dollar industry whose products do not require any promotion and advertising. Asocial lifestyle and strict bans on the use of drugs are perfect for the drug business.

Oddly enough, it is the ban on sale and use of drugs that makes this business very lucrative. For example, the production cost of one kilogram of opium in Afghanistan is 30-70 US dollars, i.e. 3-7 cents per gram. But it is sold in the US for about $\$ 40$, i.e. the sale price is approximately 550 times higher than the price of production. There is a huge financial potential in it, which is beyond the reach of legal business, even in ideal conditions.

According to the UN, the annual turnover of drugs is more than $\$ 400$ billion and is comparable to the annual budget of Germany.

UNODC has developed a model for a more qualified evaluation of the international trade of illegal narcotics, according to which this trade has the following values: $\$ 13$ billion at the manufacturer level, $\$ 94$ billion at the wholesale level, more than $\$ 400$ billion at the retail level. Thus, a large gain value is closer to the consumer level.

Today it is necessary to pay attention to the negative aspects of the world drug situation: the presence of the two planetary-scale production centres - heroin in Afghanistan and cocaine in Latin America that "have acquired a truly industrial character and provide a long-term permanent generation of the entire spectrum of threats", as well as the inextricable link between drugs, both in Russia and around the world, and transnational organized crime?

Analyzing official data on the persons who use drugs for non-medical purposes, it should be pointed to the imperfection of the accounting system, which is characterized by the incomplete interpretation of an accounting object and the lack of a common approach to the registration of drug addicts. You also need to consider that due to high latency of drug abuse, the official statistics do not fully reflect the number of drug users, the actual number of which is many times higher than the official statistics ${ }^{10}$.

In the Russian Federation about 600 thousand people are registered in drug treatment clinics (in 2014 - 656,000 people, a decrease rate was $9.3 \%$ ). However, more than 7 million people use drugs for non-medical purposes ${ }^{11}$. The high 
level of narcotization of the Russian population is a direct threat to security and a major factor of undermining the demographic and socioeconomic potential of the country.

Combating the drug threat is one of the key elements of the National Security Strategy of the Russian Federation (approved by the Decree of the President of the Russian Federation No. 683dated December 31, 2015), the Strategy of the State Anti-Drug Policy of Russian Federation until 2020 (approved by the Decree of the President of the Russian Federation No. 690of June 9, 2010), as well as the administrative and criminal law.

At present, the effectiveness of the state policy in the field of combating the drug threat, including narcoterrorism, can be illustrated by the results of the activities of certain entities of antidrug and antiterrorist activities in Russia.

Thus, according to the official data of the Russian Interior Ministry, 234.8 thousand crimes related to drug trafficking were revealed in $2015^{12}$. The law enforcement bodies investigated 14.1 thousand drug-related crimes committed in organized forms, which is $14.3 \%$ more than in 2014 . 13.2 thousand members of organized criminal groups and communities were prosecuted, which is $18.8 \%$ more than in 2014 .

A special role in supplying "heavy" drugs to the territory of the Russian Federation belongs to an ethnic drug-related crime.

In 2015 a growth in the number of arrests for the wholesale supplies of drugs by foreign citizens was by $30 \%$, and nearly by 1.5 times citizens of the Russian Federation originating from foreign countries.

The law enforcement bodies of the country seized 35.5 tons of controlled substances from illegal turnover, which corresponds to 2014.

By the end of 2015 the law enforcement bodies stopped the legalization of criminal drug revenues amounting to about 1 billion rubles.
Along with the improvement of mechanisms for combating the threat of drugs within the country, the strategic priority in the area of national security is the elimination of narcoticrelated infrastructures by the distant approaches.

The main factor undermining the state security on the southern borders of the Russian Federation is the continuing large-scale production of heroin in Afghanistan forming a powerful transit flow of drugs into our country along the "Northern route" through Tajikistan, the Kyrgyz Republic, Kazakhstan, Uzbekistan; "Balkan route" through Iran and the Caucasus countries (Armenia); "Eastern route" through China and Mongolia. In 2015 about 2 tons of heroin were seized.

Along with the relentless trafficking of Afghan opiates, in recent years there has been a significant increase in illegal turnover of synthetic drugs. If in 2012 the proportion of these substances in the total weight of seized narcotic drugs by all the law enforcement bodies of the country was a little more than $3 \%$, then it reached $16 \%$ by the end of 2015 . As a result of suppressing the activities of international criminal gangs in 2015 , about 5.4 tons of synthetic drugs were seized, which is $28.3 \%$ more than in 2014 . Taking into account the cost of these substances in the retail drug market, the law enforcement bodies blocked the possibility of reinvesting tens of billions of rubles in the drug business.

The most concentrated and dangerous drugs (heroin, cannabis and synthetic drugs) are supplied to Russia from abroad. However, the simplified inspection regime at checkpoints on the state border and poor technical equipment of customs infrastructure cause extremely low efficiency of counteraction to drug smuggling. In particular, in 2015, only in the territory of Russia the Federal Drug Control Service prevented 1171 facts of drug smuggling, the Russian Interior Ministry - 345 facts, the Russian Federal Security 
Service - 82 facts, the Federal Customs Service of Russia - 36 facts, the Russian Investigative Committee -26 facts of smuggling.

Combating the proliferation and drug consumption in Russia is an integral part of the global drug problem requiring coordinated and balanced actions by the world community.

Cooperation of the law enforcement bodies with the competent authorities of the foreign states in the sphere of combating drug trafficking, despite Western sanctions and attempts of international isolation of Russia, is actively developing both in the framework of bilateral cooperation and in a multilateral format.

In 2015, a number of comprehensive international anti-drug operations were conducted, including regional anti-drug operations: "Channel Patrol" (the Kyrgyz Republic), "Channel-Synthetic-Mail” (the Russian Federation, Vladivostok), "Clean Caspian", the international anti-drug special "operation Mosaic", the international anti-drug exercises "GROM-2015" and "Arabian Monsoon-2015".

From 21 to 25 September 2015 the operation "Channel-Synthetic-Mail" was implemented in order to counter the spread of new psychoactive substances, including the use of international mail and the Internet. The operation involved anti-drug units, police, security, customs and border services of all states - the CSTO members (Collective Security Treaty Organization). According to the CSTO data, as a result of coordinated efforts of law enforcement bodies of the states-participants, over 20 tons of drugs were seized from illegal turnover, including 4.6 tons of marijuana, over 2 tons of hashish, over 1.6 ton of synthetic drugs. Colleagues from the law enforcement bodies in Iran seized more than 10 tons of highly concentrated heroin. During the operation about 2 thousand drug-related crimes were revealed, 164 firearms and about 3000 different ammunition were seized.
It should be noted that in Russia active measures have been taken to combat organized drug crime. So, in 2015, 4250 judgments were made against the organizers of drug business, though a quarter of the liquidated criminal groups was organized outside the country or had units located abroad in their structure. 13.5 thousand drug dealers, the so-called "captains of drug trafficking", were prosecuted. The law enforcement bodies seized almost 27 tons of concentrated drugs that prevented economic losses of 114 billion rubles from the results of bulk retail ${ }^{13}$.

The world and national experience, as well as the current state of the drug situation, allows us to formulate priorities to combat the threat of drugs and narcoterrorism in Russia.

1. Establishment of the international control over drug trafficking.

International cooperation is an obligatory requirement for ensuring the effectiveness of combating narcoterrorism and should be carried out on the basis and in strict compliance with the principles and norms of the international law and in accordance with the international treaties of the Russian Federation.

The main efforts of the Russian Federation in the framework of the international control should be focused on the following areas: identifying and addressing gaps in the international law in respect of the legal regulation of the international drug turnover; promotion of international initiatives in the field of combating drug trafficking and ensuring effective work of the Commonwealth of Independent States, the Shanghai Cooperation Organization and the Collective Security Treaty Organization.

Implementation of this direction largely depends on the efficiency of interaction of the Ministry of Foreign Affairs of the Russian Federation, the State Anti-Drug Committee and the National Anti-Terrorist Committee of Russia. 
2. Counter-terrorism measures directly targeted on the isolation of terrorist organizations linked with drug business.

In accordance with the Federal Law No. 35-FZ dated March 6, 2006 "On Combating Terrorism", counter-terrorism measures should be carried out in three areas: prevention of narcoterrorism, the fight against narcoterrorism, minimization and (or) liquidation of consequences of manifestations of narcoterrorism. The most important task is to detect, prevent and suppress actions of persons and organizations aimed at preparing and committing terrorist acts and other crimes of a terrorist nature.

Dissociation of terrorist organizations, whose activities are related to drug business, is primarily possible through the development of appropriate ideological beliefs and clear convictions of members of these organizations about the false purpose of existence of the organization, the inadmissibility of committing drug-related crimes.

This direction will be effectively implemented in conjunction with such measures as bringing to justice the subjects of terrorist activities in accordance with the legislation of the Russian Federation; maintaining in a constant state of readiness for effective use of manpower and resources intended to identify, prevent and combat terrorist activities; minimization and (or) elimination of consequences of the manifestations of narcoterrorism; ensuring anti-terrorist security of citizens.

3. Targeted fight against transnational organized drug crime and elimination of transnational drug delivery channels.

The particular relevance of this direction highlighted in the Russian Federation National Security Strategy, according to which the activities of transnational criminal organizations and groups associated with illicit trafficking in narcotic drugs and psychotropic substances are classified as the main threats to the state and public security.

This direction can be more effectively realized through the proper functioning of the "security belt" around Afghanistan, improving the efficiency of border control and control over the transportation infrastructures, strengthening the state border of the Russian Federation.

4. Undermining the economic foundations of the international drug business.

In our opinion, the mechanism of implementation of this direction should be the following:

- minimizing profitability of the drug business. This requires creation of favourable conditions for lawful economic activity and the simultaneous strengthening of control over the credit and financial sphere;

- active counteraction of legitimization of proceeds derived from drug-related crimes (for example, P.1 of Art. 6 of the Federal Law No. 115 dated August 7, 2001 "On counteraction of legitimization (laundering) of proceeds of crime" provides the mandatory monitoring of operations with money or other property, if the amount, for which they are committed, is equal or exceeds 600,000 rubles), the establishment of monitoring, tracking and freezing payments, assets and profits derived from criminal activity;

- implementation of such a coercive measure as confiscation of property, since it will significantly limit the possibilities of legitimization and use of criminal capital in the legal economy. The objectives of this measure are: withdrawal of money, valuables, property, tools, equipment and other means of committing a crime in order to return them to their rightful owner, or to transfer them to the ownership of the state; suppression of criminal activities, as well as prevention of new crimes.

A positive aspect in property confiscation is the fact that this measure has a direct impact on 
the 'shadow' economy and promptly prevents the criminal business. In addition, the implementation of property confiscation may significantly limit the liberalization of foreign trade activities facilitating the illegal export of capital, as well as the penetration of transnational drug groups and their splicing with the organized drug crime.

However, despite the effectiveness of this measure, there are a lot of criminal-procedural problems in its application. For example, in the Russian Federation, these problems are characterized by the existing duty for the law enforcement authorities to prove the fact of the committed crime (Article 49-51 of the Constitution, Article 8. 11, 14 of the RF Criminal Code) and the unlawful property of the suspect. In this regard, the proposals that a suspect himself must justify legal possession of his property seem quite reasonable ${ }^{14}$.

5. Improvement of the corresponding ideological support to combat narcoterrorism.

In accordance with P. 21 of the Concept of Combating Terrorism in the Russian Federation (approved by the President of the Russian Federation, October 5, 2009), this issue could be realized through the information, cultural and educational measures.

Information measures include clarifying the nature of terrorism and its social danger, as well as the formation of the persistent society's rejection of the ideology of violence. Cultural and educational measures consist in the promotion of socially significant values and creating conditions for a peaceful interethnic and interreligious dialogue. This is realized by performing common information policy in the country and the maximum use of anti-drug and anti-terrorist propaganda, including advertising.

Special attention should be paid to the anti-drug propaganda aimed at the formation of negative public attitude to trafficking and consumption of drugs, including the propaganda of healthy lifestyles, moral and physical health in the mass media. It seems that the leading role in this activity along with the mass media should be played by school and other educational institutions, family, the system of leisure institutions, church and the system of masscommunicative influence, military-patriotic organizations, volunteer movements and others ${ }^{15}$.

At the same time the propaganda needs to be aimed at the social elimination of narcotic drugs as a dangerous object and a product of consumption in society depriving them of their attractiveness. This is possible through the active media coverage of law enforcement successes in preventing and combating drug-related crimes, the discussion of the effects of drug abuse at the level of investigative journalism and author's programs, as well as bringing to public the information on court decisions in criminal cases.

6. Prevention of corruption and corruption crimes among law enforcement officers engaged in combating narcoterrorism.

Despite the active measures undertaken in this area, corruption among the law enforcement officers is a serious concern for combating narcoterrorism effectively. Thus, in the territory of the Russian Federation in 2015, there were identified 800 employees of the law enforcement bodies and military organizations who were engaged in drug trafficking.

The law enforcement officers have got the authorities of a criminal-procedural, investigative, administrative and legal nature, as well as other measures of state coercion, therefore their activity is under close attention of society. Corrupt behaviour causes a wide public resonance and undermines the authority of the state power ${ }^{16}$.

7. Measures aimed at reducing the demand for narcotic drugs.

Measures to reduce the demand for drugs, in accordance with the Strategy of the State Anti-Drug Policy of the Russian Federation until 
2020 aimed at reducing consumption and adverse social consequences of such consumption, suggest the priority of prevention, which is not related to the application of criminal sanctions and other measures of criminal law (the priority of measures of a social, administrative and medical character). The system of these measures includes the following:

- state prevention of non-medical drug use defined as a complex of political, economic, legal, social, medical, pedagogical, cultural, physical training and sports and other measures aimed at preventing the emergence and spread of the nonmedical drug use and addiction;

- narcological medical assistance involving early detection and treatment of persons who illegally use drugs, and also reducing their mortality;

Medical and social rehabilitation of drug addicts defined as a set of measures (medical, psychological, educational, legal and social) aimed at restoration of health in all its aspects (physical, mental, spiritual and social) and the ability to function in society without drug use.

However, in modern conditions there must be other ways to combat narcoterrorism, among which the following should be noted:

- emphasizing the role of the non-medical use of drugs as a funding channel for narcoterrorism and other forms of organized crime in the process of formation of a public opinion;

- implementation of public strategies on the drug abuse prevention and rehabilitation of drug addicts in order to reduce demand for drugs among addicts. It requires concerted actions by all anti-drug, supervisory, medical and counselling services;

- study and widespread introduction of the most successful "model projects" in the field of drug prevention, rehabilitation and resocialization of drug addicts;

- arranging of monitoring and coordination of measures that should become an integral part of strategic intelligence in the field of drug control and law enforcement;

- more active use of measures against the legitimization (laundering) of money that must be included in any investigations and prosecutions of drug-related crimes.

In conclusion it should be recognized that drug trafficking and narcoterrorism as social phenomena are practically indestructible at the present time. However, by joint efforts of all the participants of anti-terrorist activities, we could achieve positive results on combating narcoterrorism and, thus, greatly reduce the threat to national security in the Russian society.

\footnotetext{
Hartelius, J. Narcoterrorism Policy Paper 3/2008 (c) EastWest Institute and the Swedish Carnegie Institute, p.3 https:// www.ciaonet.org/attachments/823/uploads

2 Hartelius, J. Narcoterrorism Policy Paper 3/2008 (C) EastWest Institute and the Swedish Carnegie Institute, p.4 https:// www.ciaonet.org/attachments/823/uploads

3 Davids, D.J. Narcoterrorism - A Unified Strategy to Fight a Growing Terrorist Menace / D.J. Davids. - Transnational Publishers, Ardsley (NY), 2002. p.4.

4 Hartelius, J. Narcoterrorism Policy Paper 3/2008 (C) EastWest Institute and the Swedish Carnegie Institute, p.3 https:// www.ciaonet.org/attachments/823/uploads

5 Declaration on Measures to Eliminate International Terrorism: 09.12.1994 adopted by Resolution 49/60 at the 84th plenary session of the UN General Assembly) // The Current International Law. T. 3 - M.: Moscow Independent Institute of International Law, 1997. p. $90-94$.

6 Hartelius, J. Narcoterrorism Policy Paper 3/2008 (C) EastWest Institute and the Swedish Carnegie Institute, p.3 https:// www.ciaonet.org/attachments/823/uploads

7 The World Drug Report 2016. p.9-10 https://www.unodc.org/doc/wdr2016/WORLD_DRUG_REPORT_2016_web.pdf

8 Report of the International Committee for Drug Control for 2015 on the implementation of Art. 12 United Nations Convention against Illicit Traffic in Narcotic Drugs and Psychotropic Substances of 1988. http://www.unis.unvienna.org/unis/ protected/2016/AR_press_kit_R.pdf

9 Actual Problems of Implementation of Strategy the State Anti-Drug Policy: presentation by Ivanov V.P., director of FDCS of Russia at the scientific-practical conference March 3, 2016 (Moscow State University). http://www.fskn.gov.ru/includes/ periodics/speeches_fskn/2016/0303/111542908/detail.shtml
} 
10 Nevirko, D.D. Countering the Threat of Drugs and Cooperation in the Field of Rehabilitation and Resocialization of Drug Users at the International and National Levels in Modern Conditions / Nevirko D.D. // National and International Level to Counter the Threat of Drugs and Cooperation in the Field of Rehabilitation and Resocialization of Drug Users: materials of XVIII International Scientific and Practical Conference (April 16-17, 2015) - Krasnoyarsk: Siberian Institute of Law of FDCS of Russia, 2015 - Part 1. p. 14-16.

11 Interview of the Chairman of the State Anti-Drug Committee, Director of Federal Drug Control Service of Russia Ivanov V.P., Russian news agency TASS March 11, 2016 http://www.fskn.gov.ru/includes/periodics/speeches_ fskn/2016/0311/093143099/detail.shtml

12 State of Crime - January-December 2015 http://mvd.ru/folder/101762/item/7087734.

13 Speech by Ivanov V.P., director of FDCS of Russia at the final meeting of the Board of Russian Federal Drug Control Service February 18, 2016. http:/www.fskn.gov.ru/includes/periodics/speeches fskn/2016/0218/121242644/detail.shtml

14 In the Future with Hope: presentations by Russian FDCService director Ivanov V.P, May-June 2013 - M., 2013. p.45-46.

15 Stepanova, E. The Role of Drug Trafficking in the Political Economy of Conflicts and Terrorism / EA Stepanova. - M .: Publishing House «Ves Mir», 2005.

16 Malkov, S. Issues of Prevention of Corruption Crime in the Drug Control Authorities /Malkov S.M., Tokmantsev D.V. Krasnoyarsk: Siberian Institute of Law of FDCS of Russia, 2016. p. 47.

\section{References}

Hartelius, J. Narcoterrorism Policy Paper 3/2008 C EastWest Institute and the Swedish Carnegie Institute, p.3-4 https://www.ciaonet.org/attachments/823/uploads

Davids, D.J. Narcoterrorism - A Unified Strategy to Fight a Growing Terrorist Menace / D.J. Davids. - Transnational Publishers, Ardsley (NY), 2002. p.4

Deklaratsia o merakh po likvidatsii mezhdunarodnogo terrorizma: [Declaration on Measures to Eliminate International Terrorism]: 09.12.1994 adopted by Resolution 49/60 at the 84th plenary session of the UN General Assembly) // The Current International Law. T. 3 - M.: Moscow Independent Institute of International Law, 1997. pp 90- 94.

The World Drug Report 2016. p.9-10 https://www.unodc.org/doc/wdr2016/WORLD_DRUG_ REPORT_2016_web.pdf

Report of the International Committee for Drug Control for 2015 on the implementation of Art. 12 United Nations Convention against Illicit Traffic in Narcotic Drugs and Psychotropic Substances of 1988. http://www.unis.unvienna.org/unis/protected/2016/AR_press_kit_R.pdf

Aktualnye problemy realizatsii strategii gosudarstvennoi antinarkoticheskoi politiki [Actual Problems of Implementation of Strategy the State Anti-Drug Policy]: presentation by Ivanov V.P., director of FDCS of Russia at the scientific-practical conference March 3, 2016 (Moscow State University). http://www.fskn.gov.ru/includes/periodics/speeches_fskn/2016/0303/111542908/ detail.shtml

Nevirko, D.D. Protivodeistvie narkougroze $i$ vzaimodeistvie $v$ sfere reabilitatsii $i$ resotsializatsii narkopotrebitelei na mezhdunarodnom i natsionalnom urovnyakh $v$ sovremennykh usloviakh [Countering the Threat of Drugs and Cooperation in the Field of Rehabilitation and Resocialization of Drug Users at the International and National Levels in Modern Conditions] / Nevirko D.D. // National and International Level to Counter the Threat of Drugs and Cooperation in the Field of Rehabilitation and Resocialization of Drug Users: materials of XVIII International Scientific and Practical Conference (April 16-17, 2015) Krasnoyarsk: Siberian Institute of Law of FDCS of Russia, 2015 - Part 1. p. 14-16.

Intervyu predsedatelya gosudarstvennogo antinarkoticheskogo komiteta [Interview of the Chairman of the State Anti-Drug Committee], Director of Federal Drug Control Service of Russia Ivanov V.P., Russian news agency TASS March 11, 2016 http://www.fskn.gov.ru/includes/periodics/ speeches_fskn/2016/0311/093143099/detail.shtml 
State of Crime - January-December 2015 http://mvd.ru/folder/101762/item/7087734.

Vystuplenie direktora FSKN Rossii Ivanova V.P.na itogovom zasedanii Kollegii FSKN Rossii [Speech by Ivanov V.P., director of FDCS of Russia at the final meeting of the Board of Russian Federal Drug Control Service] February 18, 2016.

$V$ budushchee s nadezhdoi [In the Future with Hope]: presentations by Russian FDCService director Ivanov V.P, May-June 2013 - M., 2013. p.45-46.

Stepanova, E. Rol narkobiznesa v politekonomii konfliktov $i$ terrorizma [The Role of Drug Trafficking in the Political Economy of Conflicts and Terrorism] / Stepanova E.A. - M .: Publishing House "Ves Mir", 2005.

Malkov, S. Problemy profilaktiki korruptsionnoi prestupnosti v organakh narkokontrolya [Issues of Prevention of Corruption Crime in the Drug Control Authorities] /Malkov S.M., Tokmantsev D.V. Krasnoyarsk: Siberian Institute of Law of FDCS of Russia, 2016. p. 47.

\title{
Наркотерроризм как угроза \\ национальной безопасности российскому обществу
}

\author{
Д.Д. Невирко \\ Сибирский федеральнылй университет \\ Россия, 660041, Красноярск, пр. Свободный, 79
}

В статье представлен анализ понятий наркотерроризма и авторское понимание данного явления. Описано состояние наркоситуации в мире и в Российской Федерации. Рассмотрень факторы, подрывающие систему государственной безопасности; обоснована необходимость сотрудничества правоохранительных органов России с компетентными органами иностранных государств для противодействия незаконному обороту наркотиков. Сформулированы приоритетные направления противодействия наркоугрозе и наркотерроризму в российском обществе.

Ключевые слова: наркотерроризм, наркоситуация, терроризм, наркотизация населения, противодействие наркотерроризму, наииональная безопасность.

Научная специальность: 22.00.00 - социологические науки. 